\title{
DIFFERENCES IN SPATIAL STRUCTURE OF RURAL AREAS OF COMMUNE OF GORAJ WITH REGARD TO SIZE OF FARMS OWNED BY NATURAL PERSONS
}

\author{
Pawel Postek \\ University of Life Sciences in Lublin, Poland \\ pawel.postek@up.lublin.pl
}

\begin{abstract}
Agriculture in Poland varies from region to region in terms of the level of farming culture and intensity of production. The majority of holdings are family farms, which use extensive farming practices and which are geared towards multidirectional production. They are characterized by low product marketability. Small farms with an area of 1-5 ha prevail. The largest fragmentation of individual farms is observed in the southern and south-eastern parts of the country. A more favourable agrarian structure is found in northern Poland. The defective structure can be improved using land consolidation measures, which additionally contribute to the sustainable development of rural areas, including the creation of more favourable conditions for farming and forestry, by improving farm layout and equipping the areas being restructured with technical and social infrastructure. What surface area is occupied by individual farms is a decisive factor that determines both the pertinence of implementing land consolidation and exchange measures in a given area, and the likely outcomes of such interventions. The selection of areas (villages) with the highest percentage of privately owned farmland is an important step in developing prioritization schemes for consolidation interventions, because consolidation is supposed to bring measurable benefits in the form of improving the spatial structure of farms. The aim of this article was to classify villages in terms of the percent of agricultural land. The data concerned 15 villages of the commune of Goraj, occupying a total area of 6792.86, divided into 21417 land parcels (cadastral plots). The classes of villages identified in the study can be used as a criterion for determining the order in which the villages should be subjected to land consolidation and exchange.
\end{abstract}

Keywords: land consolidation, farms, ranking, zero unitarisation.

\section{Introduction}

The Lublin region, located in Eastern Poland, is a strongly agricultural area. The favourable soil and climate conditions that characterize this territory and a large share of arable land provide an excellent environment for agricultural activity. The Lubelskie Voivodship is a leader in the production of many field and fruit crops. Both in the Lublin Province (Voivodship) and throughout Poland, there are differences in the level of farming culture and production intensity among various areas and regions. Over the centuries, the spatial structure of the Polish countryside has been shaped by historical, legal, socio-economic, political, technical, and demographic conditions [1]. A characteristic feature of land is the fact that it is a part of nature used for crop production, which, not being a product of human labour, cannot be enlarged or replaced with another means of production [2]. An agricultural holding is a single unit, technically and economically, operating under a single management, which undertakes agricultural activities A privately-owned agricultural holding is an agricultural holding owned by a natural person. Privately-owned agricultural holdings include:

- farms with 1 ha or more of agricultural land,

- farms with an area of less than 1 ha of agricultural land (including those with no agricultural land), which pursue activity in special agricultural production or in production on a substantial scale (specified by relevant thresholds), e.g., production of fruit trees, fruit bushes, fruit trees and ornamental plants in nurseries, vegetables and open-field strawberries, hops, tobacco, goats, and wild animals [3].

The operation and profitability of every farm depends on whether or not agricultural production brings measurable benefits. Each holding aims at obtaining maximum revenue at minimum labour input. Therefore, creating optimal conditions for agricultural production is an important task for each farm [4;5]. In many communes, a serious impediment to improving crop production conditions is that land cannot be consolidated and exchanged in all villages at the same time. This is why studies are carried out on the planning of land consolidation and exchange activities, which focus on methods of determining the order, in which these activities should be performed $[6 ; 7 ; 8 ; 9]$. Land consolidation interventions not only improve the spatial structure of farms characterized by large fragmentation [10] and scattering of land [11;12], but also allow to reclaim agriculturally useless land [13;14]. These land management measures can be used to change agricultural space in a comprehensive manner. Since 
Poland's accession to the European Union, the main priorities in the implementation of land consolidation and exchange measures have been to develop economy with a view to increasing the attractiveness of rural areas to their inhabitants, as well as to strengthen the economically sustainable development of the agricultural sector, simultaneously ensuring the sustainability of the natural environment $[15 ; 16]$.

The aim of this study was to determine the need for consolidation and exchange of land in the villages of the commune of Goraj, located in the Biłgoraj District in the Lubelskie Voivodship. To establish a consolidation priority ranking, a synthetic measure was calculated for each village using the zero unitarization method. The calculations were based on values of twelve factors that had previously been determined for every village. The obtained values of the synthetic measure allowed us to develop a prioritization scheme for consolidation interventions in the area discussed.

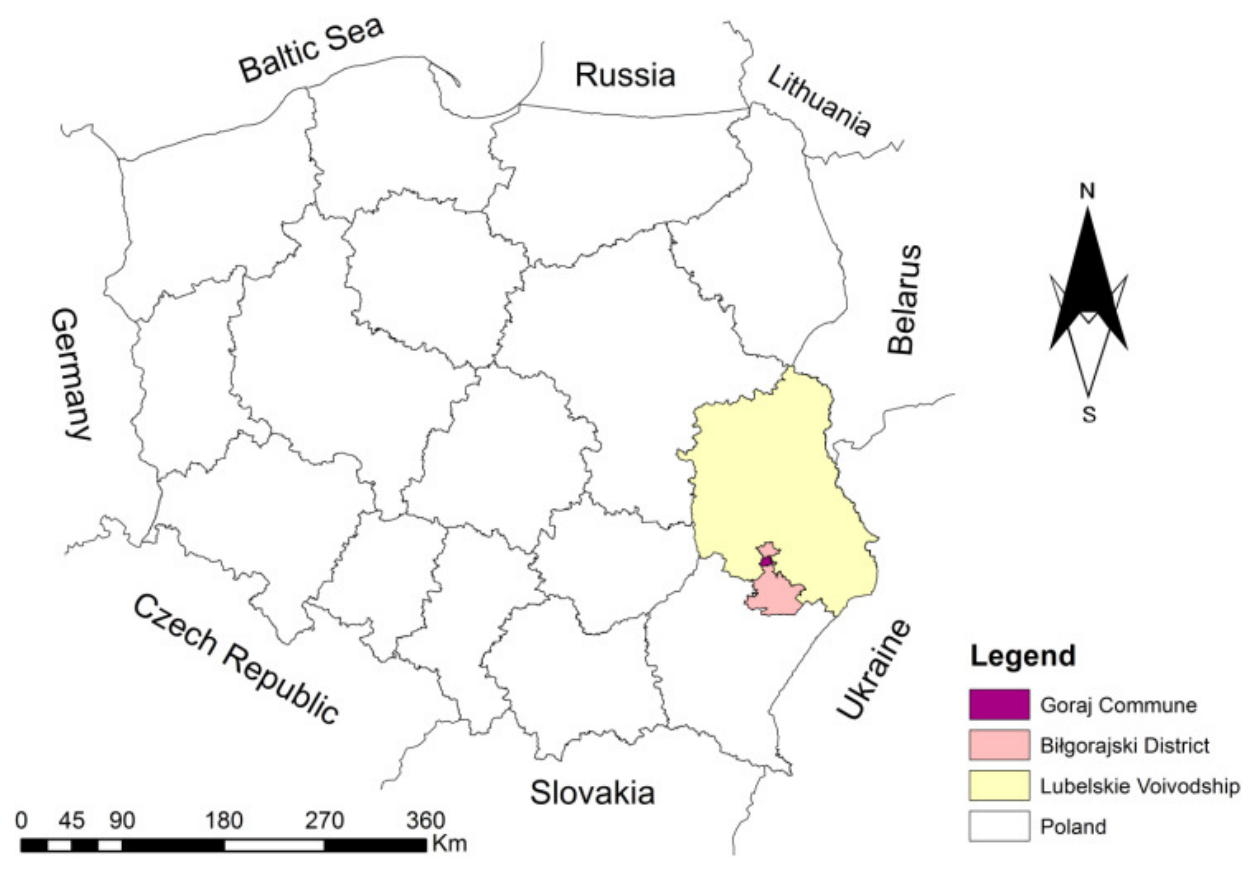

Fig. 1. Geographical situation of study area

\section{Materials and methods}

To establish differences among the rural areas of the Goraj commune in the spatial structure of land owned by natural persons, twelve factors, grouped into four thematic categories, were determined and calculated for each village. The results are given in Table 1.

Table 1

A list of factors characterizing the study area

\begin{tabular}{|c|c|c|c|}
\hline 1. General data & 2. Farmland data & 3. Property data & 4. Land use data \\
\hline $\begin{array}{c}x_{1}-\text { total surface } \\
\text { area }\end{array}$ & $\begin{array}{c}x_{4}-\% \text { of register units in the } \\
\text { "agricultural holding" } \\
\text { category }\end{array}$ & $\begin{array}{c}x_{8}-\% \text { of the number } \\
\text { of register units in the } \\
\text { "agricultural real } \\
\text { estate" category }\end{array}$ & $\begin{array}{c}x_{9}-\% \text { of area occupied } \\
\text { by arable land }\end{array}$ \\
\cline { 4 - 4 } $\begin{array}{c}x_{2}-\% \text { of area } \\
\text { occupied by } \\
\text { privately owned } \\
\text { land }\end{array}$ & $\begin{array}{c}x_{5}-\% \text { of the number of } \\
\text { plots of agricultural land out } \\
\text { of all privately owned plots }\end{array}$ & $\begin{array}{c}x_{10}-\% \text { of area occupied } \\
\text { by pastures }\end{array}$ \\
\hline $\begin{array}{c}x_{3}-\% \text { of the } \\
\text { number of privately } \\
\text { owned plots }\end{array}$ & $\begin{array}{c}x_{6}-\% \text { of area of plots of } \\
\text { agricultural land out of all } \\
\text { privately owned plots }\end{array}$ & & $\begin{array}{c}x_{11}-\% \text { of area } \\
\text { occupied by meadows }\end{array}$ \\
\hline & $\begin{array}{c}x_{7}-\text { mean number of plots in } \\
\text { a register unit }\end{array}$ & $\begin{array}{c}x_{12}-\% \text { of area } \\
\text { occupied by woodland } \\
\text { and forests }\end{array}$ \\
\hline
\end{tabular}


There are many methods for creating synthetic measures, which use diagnostic (independent) variables. The diagnostic variables are selected in a similar way to explanatory variables, by establishing a list of variables characterizing the phenomenon under study. In the present article, we used the zero unitarisation method, which allows to standardize diagnostic variables by studying the range of a feature [17]. The diagnostic variables, which describe a given object, can be divided into three groups [18].

1. Stimulants - variables, which increase in value leads to an increase in the value of a diagnostic feature of the object under consideration; in this case, standardized variables are calculated from the following formula:

$$
Z=\frac{\left(x-x_{\min }\right)}{\left(x_{\max }-x_{\min }\right)} .
$$

2. Destimulants - variables, which increase in value leads to a decrease in the value of a diagnostic feature of the object under consideration; in this case, standardized variables are calculated from the following formula:

$$
Z=\frac{\left(x_{\max }-x\right)}{\left(x_{\max }-x_{\min }\right)} .
$$

3. Nominants - variables, which only take on the highest rating (optimum) for a certain value or range of values; as one moves away from the optimum, the rating of the phenomenon becomes more negative; in this case, the standardized variables are calculated according to the following formula:

$$
\begin{aligned}
& Z=\frac{\left(x-x_{\min }\right)}{\left(x_{\mathrm{opt}}-x_{\min }\right)}, \text { for } x<x_{\mathrm{opt}}, \\
& Z=\frac{\left(x-x_{\max }\right)}{\left(x_{\mathrm{opt}}-x_{\max }\right)}, \text { for } x>x_{\mathrm{opt}},
\end{aligned}
$$

where $z$-standardized variable,

$x$ - variable prior to standardization,

$x_{\max }$ - maximum value of a variable in a given set,

$x_{\min }$ - minimum value of a variable in a given set,

$x_{\mathrm{opt}}$ - optimum value of a variable in a given set.

The standardization of diagnostic features is a preliminary step, which leads to a consolidated multi-criteria evaluation of each of the objects under consideration. The consolidated evaluation of each object is obtained by aggregation. In order to obtain a synthetic measure, average values of the sets characterizing the respective features are calculated using the following formula:

$$
z_{i}=\frac{1}{p} \sum_{j=1}^{p} x_{i j}(i=1, \ldots, n) .
$$

Standardized measures are in the range $<0 ; 1>$. Results are interpreted as the average of the optimum values achieved by each object. Accordingly, the higher the value of the synthetic measure, the higher the position of the object in the ranking.

\section{Results and discussion}

The values of the synthetic measure obtained in the study allowed us to determine differences in the spatial structure of rural areas in the commune of Goraj with regard to the structure of privately owned farmland. The division of villages into groups was made on the basis of expert knowledge. The results are given in Table 2, and a map showing the differences in a graphic form is given in Fig. 2. 
Values of the synthetic measure for the villages of the commune of Goraj

Table 2

\begin{tabular}{|c|c|c|}
\hline No. & $\begin{array}{c}\text { Value of synthetic } \\
\text { measure }\end{array}$ & Name of village \\
\hline 1 & 0.817 & Hosznia Ordynacka \\
\hline 2 & 0.801 & Zagrody \\
\hline 3 & 0.778 & Zastawie \\
\hline 4 & 0.771 & Goraj \\
\hline 5 & 0.730 & Wólka Abramowska \\
\hline 6 & 0.687 & Kondraty \\
\hline 7 & 0.672 & Hosznia Abramowska \\
\hline 8 & 0.622 & Majdan Abramowski \\
\hline 9 & 0.614 & Las Ładzki \\
\hline 10 & 0.604 & Jędrzejówka \\
\hline 11 & 0.516 & Gilów \\
\hline 12 & 0.395 & Abramów \\
\hline 13 & 0.374 & Bononia \\
\hline 14 & 0.318 & Albinów \\
\hline 15 & 0.277 & \\
\hline
\end{tabular}
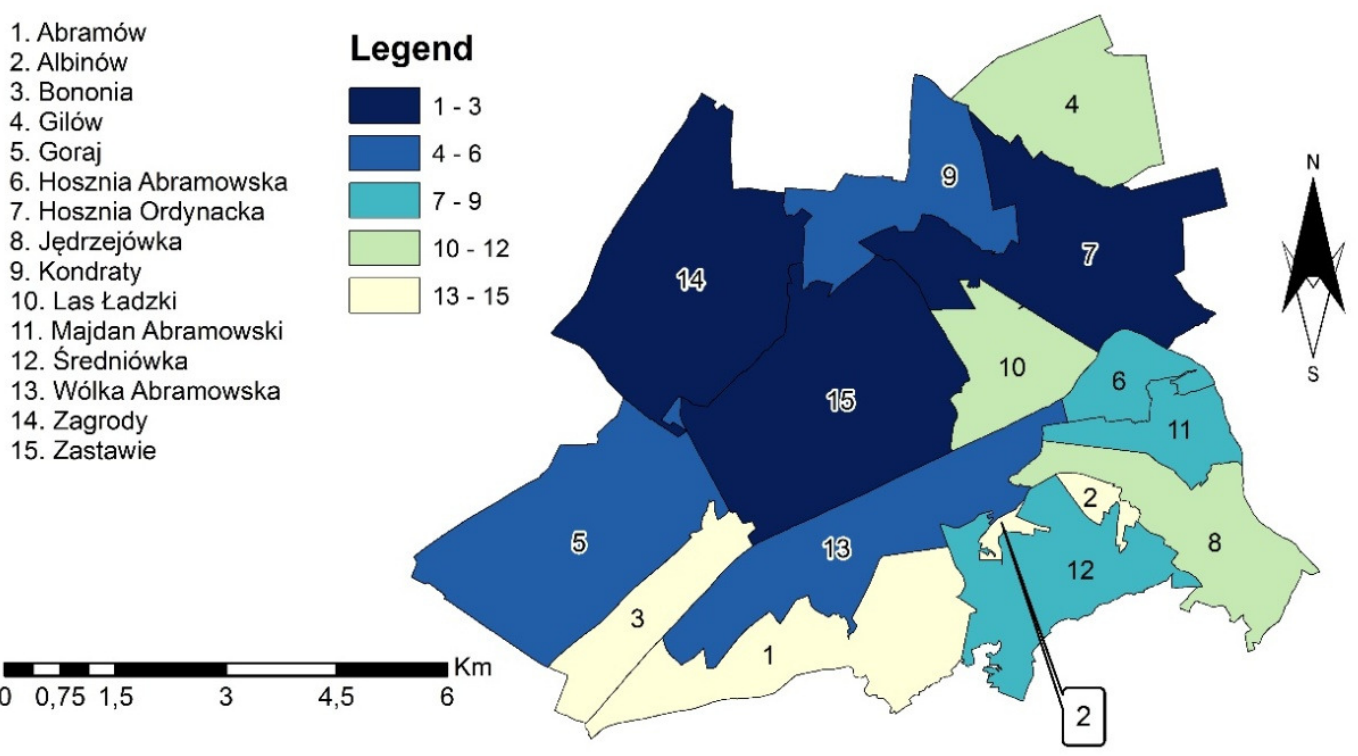

Fig. 2. Map showing differences in spatial structure among villages of commune Goraj

The villages of the commune of Goraj had different values of the synthetic measure. As shown in Figure 2, the villages were grouped into larger clusters, in which consolidation can be performed under one scheme. As can be seen from Table 2 and Figure 2, the villages, in which consolidation measures should be introduced first, include Hosznia Ordynacka, Zagrody and Zastawie. These villages are adjacent to each other and are characterized by similar land structure defects, which means that they can be combined into a larger typological unit. Combining several villages into a cluster is a helpful strategy in cases where land consolidation and exchange measures cannot be introduced in all villages of a commune simultaneously. Therefore, it is advisable to use a synthetic measure to establish the priority of land consolidation interventions in a study area.

The next group of villages, which require consolidation most urgently, are Goraj, Wólka Abramowska, and Kondraty, for which the synthetic measure was in the range of 0.687-0.771. As a 
next step, the land consolidation project should be implemented in Średniówka and the neighbouring villages of Hosznia Abramowska and Majdan Abramowski. Consolidation in the remaining villages should be performed in accordance with the ranking shown in Table 2 and Figure 2.

\section{Conclusions}

1. In Poland, many farm holdings have numerous plots of land scattered over a wide area.

2. For Polish agriculture to become more competitive, measures must be taken to improve the landdistribution structure of farms by providing financial support for the consolidation of agricultural and forestry land.

3. The method of identifying areas with similar structure of agricultural land presented in this study can be used in preliminary selection of areas for land consolidation, as it provides valuable information on the size of the farms in the area studied.

4. A great advantage of this approach is that the synthetic measure calculated for each village provides information on the percent of area occupied by parcels owned by natural persons and the number of such parcels as percent of all farmland, because it is the owners of these parcels. The main reason of land consolidation is to create more favourable conditions for farming and forestry by improving the land-distribution structure of agricultural holdings.

5. Therefore, the method presented in this study can be used as a tool for preliminary selection of areas, which require land consolidation most urgently.

\section{References}

[1] Noga K. Wpływ różnych czynników na zmiany użytkowania gruntów we wsiach górskich (The effect of various factors on changes in land use in mountain villages). A National Conference of the Polish Federation of Engineering Associations (NOT), 1978, Białystok, (In Polish)

[2] Whitehead G. Ekonomia (Economics Made Simple) , 2001, Poznań, Wydawnictwo Zysk i S-ka, (In Polish)

[3] Act of 23 April 1964. Civil Code (Official Journal of Laws, 2017, Item 459, consolidated text with later amendments), (In Polish)

[4] Sobolewska-Mikulska K. (Ed.) Współczesne scalania gruntów w kształtowaniu granic rolniczej przestrzeni produkcyjnej (Contemporary land consolidation in shaping the borders of the agricultural production space). 2015, Oficyna Wydawnicza Politechniki Warszawskiej, (In Polish)

[5] Sobolewska-Mikulska K. Procedury prawno-geodezyjne w gospodarce gruntami na obszarach rolnych (Legal-and-land-surveying procedures in the management of land in rural areas). Warszawa: Oficyna Wydawnicza Politechniki Warszawskiej, 2015. pp. 23, (In Polish)

[6] Len P. Methodology of hierarization of the work of land consolidation and land exchange.The World Multidisciplinary Earth Sciences Symposium (WMESS 2017).IOP Conf.Series: Earth and Environmental Science 95 (2017) 032010, September 11-15, 2017, Prague, DOI :10.1088/17551315/95/3/032010

[7] Len P., Mika M. Determination of the urgency of undertaking land consolidation works in the villages of the Sławno municipality.Journal of Ecological Engineering.Volume 17, Issue 4, Sept.2016, pp. 163-169DOI: 10.12911/22998993/64827.

[8] Leń P., Noga K. Prioritization of Land Consolidation Interventions in the Villages of Central Poland. Journal of Ecological Engineering, Volume 19, Issue 2, March 2018, pp. 248-256.

[9] Len P., Oleniacz G., Skrzypczak I., Mika M. The Hellwig's and zero unitarisation methods in creating a ranking of the urgency of land consolidation and land exchange work. International Multidisciplinary Scientific GeoConference SGEM 2016, www.sgem.org, SGEM2016 Conference Proceedings, ISBN 978-619-7105-59-9 / ISSN 1314-2704, June 28 - July 6, 2016, Book2 Vol. 2, pp. 617-624. DOI: 10.5593/SGEM2016/B22/S09.080.

[10] Strek Z. Engineering for rural development analysis of demand for land consolidation in Milejów commune, Łęczna district. ENGINEERING FOR RURAL DEVELOPMENT, Jelgava, May 24.26, 2017, pp. 593-599, DOI: 10.22616/ERDev2017.16.N119.

[11] Leń, P., Król, Z. Analysis of economic and environmental effects of land consolidation on the example of Hucisko village.Journal of Ecological Engineering.Volume 17, Issue 5, Nov.2016, pp. 232-239.DOI: 10.12911/22998993/65090. 
[12] Wójcik-Leń J., Stręk Ż., 2017. Proposal for land consolidation project solutions for selected problem areas. World Multidisciplinary Earth Sciences Symposium (WMESS 2017).Earth and Environmental Science 95 (2017) 032016, September 11-15, 2017, Prague, DOI :10.1088/1755$1315 / 95 / 3 / 032016$

[13] Wójcik-Leń J., Sobolewska-Mikulska K., Specific features of development of selected agricultural problematic areas in the land consolidation process.Journal of Water and Land Development, 2017, No. 34, pp. 249-258, DOI:10.1515/jwld-2017-0060.

[14] Wójcik-Leń J., Sobolewska-Mikulska K. Issues related to marginal lands with reference to selected agricultural problematic areas.Journal of Water and Land Development, 2017, No. 35, pp. 265-273, DOI:10.1515/jwld-2017-0093.

[15] Dudzinska M., Kocur-Bera K. Land consolidation as the driving force behind ecological and economic development of rural areas. Conference: 9th International Conference on Environmental Engineering (ICEE) Location: Vilnius, Lithuania,May 22-23, 2014

[16] Dudzinska M., Kocur-Bera K. Community Education and Integrated Organization of Rural Areas based on Land Consolidation Processes in Poland. Conference: 8th International Scientific Conference on Rural Environment, Education and Personality Location: Jelgava, Latvia, May 1516, 2015 Rural Environment, Education, Personality (REEP), Vol 8 Book Series: Rural Environment Education Personality, Issue: 8, pp. 34-41

[17] Jędrzejczyk Z., Kukuła K., Skrzypek J., Walkosz A. Badania operacyjne w przykładach i zadaniach, Wydawnictwo Naukowe (Operational research in examples and tasks), PWN, Warszawa, 2002, (In Polish)

[18] Kukuła K. Metoda unitaryzacji zerowanej (Zero Unitarisation Method), PWE, Warszawa, 2000, (In Polish) 